\title{
PENGARUH KETIDAKPASTIAN LINGKUNGAN, DESENTRALISASI DAN PEMBEBANAN TUGAS TERHADAP PELAPORAN KEUANGAN BERBASIS AKRUAL
}

\author{
Pandu Prameswari, Kurnia Nur Handayani \\ Sekolah Tinggi Ilmu Ekonomi Indonesia (STIESIA) Surabaya
}

\begin{abstract}
The amendment of Government Regulation No. 24 of 2005 to Government Regulation No. 71 of 2010 based on accruals, made the government, especially the local government must apply and implement it no later than 5 years, namely in 2015. However, until now there are still many who do not fully understand the accounting-based accruals. There are various factors that influence government's preparedness and readiness in implementing accrual basis financial reporting. This study aims to analyze and examine the effects of environmental uncertainty, decentralization and assignment to accrual basis financial reporting. Population and sample in this research are Financial Administration Official of Regional Finance Organization (PPK-OPD) and Regional Finance Administration (PPKD) in Sidoarjo Regency. The study was conducted on 13 Local Government Organizations. The research method is quantitative and analytical technique using Multiple Linear Regression with SPSS data statistic application. The results of this study indicate that environmental uncertainty, decentralization and assignment have an effect on the accrual based financial reporting.
\end{abstract}

Keywords

Correspondence to
: Environmental uncertainty, decentralization, task loading, Accrual based financial reporting

:momoepanda@gmail.com

\begin{abstract}
ABSTRAK
Perubahan Peraturan Pemerintah Nomor 24 Tahun 2005 menjadi Peraturan Pemerintah Nomor 71 Tahun 2010 berbasis akrual, membuat pemerintahan khususnya pemerintah daerah wajib mengaplikasikan dan menerapkannya selambat-lambatnya 5 tahun, yaitu tahun 2015. Namun hingga saat ini masih banyak yang belum paham sepenuhnya dengan akuntansi berbasis akrual. Ada berbagai faktor yang mempengaruhi pemahaman dan kesiapan pemerintah dalam menerapakan pelaporan keuangan berbasis akrual. Penelitian ini bertujuan untuk mengetahui dan menguji pengaruh ketidakpastian lingkungan, desentralisasi dan pembeban tugas terhadap pelaporan keuangan berbasis akrual. Populasi dan sampel dalam penelitian ini adalah Pejabat Penatausahaan Keuangan Organisasi Pemerintahan Daerah (PPK-OPD) dan Pejabat Penatausahaan Keuangan Daerah (PPKD) di Kabupaten Sidoarjo. Penelitian dilakukan pada 13 Organisasi Pemerintahan Daerah. Metode penelitian yaitu kuantitatif dan teknik analisis menggunakan Regresi Linier Berganda dengan aplikasi statistik data SPSS. Hasil dari penelitian ini menunjukkan bahwa ketidakpastian lingkungan, desentralisasi dan pembebanan tugas berpengaruh terhadap pelaporan keuangan berbasis akrual.
\end{abstract}


Kata kunci

Korespondensi
: Ketidakpastian lingkungan, desentralisasi, pemuatan tugas, pelaporan keuangan berbasis akrual

:momoepanda@gmail.com

\section{PENDAHULUAN / INTRODUCTION}

Seiring dengan perkembangan zaman dan semakin meningkatnya kebutuhan entitas bisnis akan informasi mengakibatkan informasi juga mengalami perubahan yang sangat cepat. Akuntansi manajemen merupakan salah satu jenis informasi yang dibutuhkan oleh manajemen dalam memprediksi konsekuensi yang mungkin terjadi atas berbagai alternatife tindakan yang dapat dilakukan dalam melaksanakan fungsifungsi manajemen seperti perencanaan, pengawasan dan pengambilan keputusan. Oleh sebab itu, suatu organisasi tidak akan berjalan mulus tanpa adanya manajemen yang merupakan satu kelompok utuh dari organisasi yang terdiri dari manajer, direktur, dewan direksi dan sebagainya. Akuntansi dapat dipandang dari dua sudut sisi, yaitu akuntansi manajemen sebagai tipe akuntansi dan akuntansi manajemen sebagai tipe informasi. Pemahaman yang baik mengenai karakteristik akuntansi manajemen sebagai salah satu tipe akuntansi akan membantu pemahaman karakteristik dan perekayasaan informasi akuntansi manajemen. Sebagai salah satu tipe informasi, akuntansi merupakan sistem yang mengelola masukkan yang berupa data informasi atau data keuangan untuk menghasilkan keluaran berupa informasi akuntansi yang dibutuhkan oleh pemakai, dimana fungsi utama akuntansi adalah menyediakan informasi untuk pengambilan keputusan bagi para pengguna informasi (Rini, 2007). Salah satu pihak yang menggunakan informasi akuntansi adalah manajer. Manajer menggunakan informasi akuntansi untuk tujuan pengambilan keputusan yang berkaitan dengan perencanaan dan pengendalian organisasi. Informasi akuntansi merupakan sumber informasi penting yang membantu manajemen mengendalikan aktivitasnya serta mengurangi masalah ketidakpastian lingkungan dalam rangka mencapai tujuan organisasi. Ketika unsur dalam suatu organisasi menjadi semakin kompleks, pihak manajemen membutuhkan informasi yang dapat mendukung dalam membuat keputusan manajerial.

Menurut Rizna (2009), Informasi Sistem Akuntansi Manajemen didefinisikan sebagai suatu informasi formal yang telah didesain untuk mempermudah pengambilan keputusan dan mengevaluasi aktivitas manajerial dan memenuhi karakteristik informasi Sistem Informasi Manajemen (SAM) yaitu broad scope, timeliness, aggregation dan integration. Salah satu fungsi sistem akuntansi manajemen (SAM) adalah suatu mekanisme kontrol organisasi, serta merupakan alat yang cukup efektif didalam menyediakan informasi yang bermanfaat guna memprediksi konsekuensi yang mungkin terjadi dari aktifitas yang bisa dilakukan. Perubahan lingkungan juga memegang peranan yang sangat penting bagi kelangsungan hidup suatu organisasi. Lingkungan organisasi telah berubah seiring perubahan zaman, dengan tingkat ketidakpastian lingkungan yang semakin tinggi. Ketidakpastian lingkungan yang saat ini melanda berbagai aspek kehidupan mulai 
dari aspek ekonomi, politik, sosial dan budaya menuntut manajer untuk menyiapkan diri dan perusahaan dalam menghadapi perubahan yang cepat.

Informasi dalam sistem desentralisasi lebih banyak dibutuhkan dibandingkan dalam organisasi yang tersentralisasi. Hal ini dikarenakan sistem sentralisasi manajer hanya menjalankan perintah atasannya saja. Sebaliknya dalam desentralisasi manajer memerlukan informasi lebih banyak untuk membuat dan mengambil sebuah keputusan. Dalam yang kondisi ketidakpastian lingkungan yang semakin tinggi, bentuk struktur yang sesuai adalah desentralisasi. Hal ini disebabkan karena kondisi ketidakpastian lingkungan tinggi diperlukan suatu pengambilan keputusan yang cepat dan segera. Desentralisasi merupakan penyerahan pelimpahan wewenang dan tanggung jawab, dimana manajer line terdepan yang berhubungan langsung dengan pusat permasalahan akan memiliki otoritas untuk mengambil keputusan, sehingga keputusan dapat diambil cepat. Penyelenggaraan desentralisasi dimaksudkan untuk memberikan kewenangan yang luas, nyata dan bertanggung jawab kepada manajer secara proporsional yang diwujudkan dengan pengaturan, pembagian dan pemanfaatan sumber daya nasional yang berkeadilan, serta perimbangan keuangan. Persoalan lainnya yang muncul dengan desentralisasi adalah respon dan beban tugas setiap bagian unit kerja untuk melaksanakannya sangat berbeda antara masing-masing.

Selain itu pula, pembebanan tugas yang dalam hal ini dititik beratkan pada job descreption, dapat menjadi salah satu faktor penentu yang dapat mempengaruhi kinerja manajer. Sifat-sifat pembedaan tugas dalam research \& development secara pontensial dapat mempengaruhi keefektifan bentuk pengendalian akuntansi karena sifatnya yang tidak rutin. Rutinitas didefinisikan sebagai suatu teknologi dalam melakukan tugas-tugas yang berulang-ulang dan yang dapat diprediksi. Informasi akuntansi manajemen juga diperlukan dalam perwujudan good coorporate governance, baik di sektor publik maupun di sektor swasta. Tuntutan masyarakat agar pengelolaan negara dijalankan dengan transparan dan akuntabel sejalan dengan keinginan masyarakat Indonesia, untuk mengganti sistem akuntansi tradisional dan akuntansi berbasis kas ke sistem akuntansi berbasis akrual. Fenomena yang dapat diamati dalam perkembangan sektor publik dewasa ini adalah Komite Standar Akuntansi Pemerintah (KSAP) menerbitkan standar akuntansi pemerintah berbasis akrual yang ditetapkan melalui PP Nomor 71 Tahun 2010 tentang Standar Akuntansi Pemerintahan (SAP) menggantikan PP Nomor 24 tahun 2005 yang menggunakan basis kas menuju akrual (cash toward accrual). Tahun 2015 menjadi tahun terakhir dari batas waktu yang diberikan oleh pemerintah untuk sesuai dengan PP Nomor 71 tahun 2010 menerapkan Akuntansi Pemerintahan Berbasis Akrual (APBA).

Akuntansi berbasis akrual adalah suatu basis akuntansi dimana transaksi ekonomi dan peristiwa lainnya diakui, dicatat dan disajikan dalam laporan keuangan pada saat terjadinya transaksi tersebut, tanpa memperhatikan waktu kas atau setara kas diterima atau dibayarkan. Di dalam akuntansi berbasis akrual, waktu pencatatan (recording) sesuai dengan saat terjadinya arus sumber daya/transaksi, sehingga dapat menyediakan informasi yang paling komprehensif karena seluruh arus sumber daya dicatat. Di Indonesia, penerapan basis akrual harus dilaksanakan oleh seluruh organisasi sebagai entitas pelaporan. Selain itu, diharapkan adanya upaya pengharmonisasian berbagai peraturan pada berbagai organisasi sektor 
publik baik satuan organisasi di lingkungan pemerintah pusat maupun pemerintah daerah. Hal ini di tegaskan dalam undang-undang Nomor 17 tahun 2003 tentang Keuangan Negara dalam pasal 36 ayat (1) yang berbunyi sebagai Berikut : "Ketentuan mengenai pengakuan dan pengukuran pendapatan dan belanja berbasis akrual sebagaimana dimaksud dalam pasal 1 angka $12,14,15$, dan 16 undang-undang dilaksanakan selambat-lambatnya dalam 5 (lima) tahun. Selama pengakuan dan pengukuran pendapatan belanja berbasis akrual belum dilaksanakan, digunakan pengakuan dan pengukuran berbasis kas". Pada masing-masing satuan kerja memperoleh dana dari pemerintahan pusat melalui Kementrian Keuangan. Selanjutnya satuan kerja mengelola pendanaan tersebut secara desentralisasi bersama-sama dengan unit-unit kerja (subsatker) dibawahnya. Karena dana yang diberikan kepada satuan kerja adalah dana dari pemerintah, maka setiap unit kerja harus menggunakan dan mempertanggung jawabkannya secara akuntabel, transparan, efektif dan efisien.

Peraturan pemerintah nomor 71 tahun 2010 pasal 1 ayat (8) menyatakan bahwa: "Standar akuntansi pemerintahan berbasis akrual adalah standar akuntansi pemerintahan yang mengakui pendapatan, beban, aset, utang, dan ekuitas dalam pelaporan finansial berbasis akrual, serta mengakui pendapatan, belanja, dan pembiayaan dalam pelaporan pelaksanaan anggaran berdasarkan basis yang ditetapkan dalam APBN/APBD”. Beberapa isu penting perubahan yang perlu dipahami adalah laporan keuangan pokok yang disusun pada Standar Akuntansi Pemerintahan lama (PP No. 24 tahun 2005) terdapat di dalam Standar Akuntansi Pemerintah berbasis akrual, yaitu: (1) Laporan Realisasi Anggaran (LRA); (2) Neraca; (3) Laporan Arus Kas; (4) Catatan atas Laporan Keuangan (CaLK).
Sedangkan pada SAP baru (PP No. 71 tahun 2010) komponen laporan keuangan terdiri dari: (1) Laporan Realisasi Anggaran (LRA); (2) Laporan Perubahan Saldo Anggaran Lebih (Laporan Perubahan SAL); (3) Neraca; (4) Laporan Operasional (LO); (5) Laporan Arus Kas (LAK); (6) Laporan Perubahan Ekuitas (LPE); (7) Catatan atas Laporan Keuangan.

Akuntansi berbasis akrual dianggap memiliki sejumlah manfaat untuk organisasi sektor publik. Para pendukung penerapan basis akrual dalam organisasi sektor publik, menyakini bahwa akuntansi akrual mengakui beban ketika transaksi terjadi, dianggap menyediahkan gambaran operasional pemerintah secara lebih transparan. Manfaatmanfaat penerapan basis akrual menurut $\mathrm{H}$ Thompson dalam Widjajarso (2008), mencakup hal-hal seperti: (1) Menyediakan gambaran yang utuh atas posisi keuangan pemerintah; (2) Menunjukan bagaimana katifitas pemerintah dibiayai dan bagaimana pemerintah dapat memnuhi kebutuhan kasnya; (3) Menyediakan informasi yang berguna tentang tingkat yang sebenarnya kewajiban pemerintah; (4) Meningkatkan daya pengelolaan aset dan kewajiban pemerintah; dan (5) Basis akrual sangat familiar pada lebih banyak orang dan lebih komprehensif dalam penyajian. Namun dalam penerapannya memiliki banyak kendala dan memerlukan dana yang besar serta waktu yang sangat panjang. Kendala utama terjadi karena kurangnya tenaga akuntansi atau SDM sudah terbiasa menggunakan sistem pencatatan single entry, sehingga untuk mengubah menjadi double entry menjadi sangat sulit.

Didefinisikan secara terpisah yang dikemukakan oleh Kusrini dan Kinoyo (2007) pendekatan yang lebih menekankan pada elemen-elemen atau komponennya sistem sebagai "sekumpulan elemen yang 
saling terkait atau terpadu yang dimaksudkan untuk mencapai suatu tujuan". Informasi adalah data yang sudah diolah menjadi sebuah bentuk yang bermanfaat bagi pengambilan keputusan atau mendukung sumber informasi. Sumber informasi dapat diartikan sebagai sebuah sistem yang terdiri atas rangkaian subsistem informasi terhadap pengolahan data untuk menghasilkan informasi yang berguna bagi pengambilan keputusan. Hasil dari penelitian sebelumnya dari Kristiawati (2015) dan Wiryaningsih et al., (2017), menyatakan bahwa masih belum optimalnya penerapan Peraturan Pemerintah Nomor 71 Tahun 2010 tentang standar akuntansi pemerintah berbasis akrual.

Perbedaan dari penelitian sebelumnya adalah objek penelitian ini dilakukan pada OPD Pemerintah Daerah yakni Pemerintah Kabupaten Sidoarjo, alasan pada Pemerintahan Kabupaten Sidoarjo karena laporan keuangan Pemerintah Kabupaten Sidoarjo mendapatkan opini Wajar Tanpa Pengecualian dari Badan Pemeriksa Keuangan pada tahun 2014 dan tahun 2015 serta untuk mempertahankan opini yang telah didapat oleh Pemerintah Kabupaten Sidoarjo untuk tahun-tahun berikutnya, selain itu untuk mengetahui seberapa efektif penerapan akuntansi berbasis akrual dimana dalam penelitian ini mengaplikasikan pada pelaporan keuangan berbasis akrual. Menurut Novian Herodwijayanto menjelaskan bahwa tahun ini merupakan pemeriksaan keuangan pertama dengan menggunakan basis akrual. "Tahun 2015 merupakan tahun pertama dimana seluruh pemerintah baik pemerintah pusat maupun pemerintah daerah diwajbkan untuk menerapkan akuntansi berbasis akrual, tentu saja proses migrasi ini merupakan tantangan yang tidak kecil, tidak hanya pada pemerintah pusat maupun daerah tetapi juga para pemeriksa itu sendiri". Penelitian ini bertujuan untuk menguji ketidakpastian lingkungan, desentralisasi dan pembebanan tugas terhadap pelaporan keuangan berbasis akrual.

\section{TINJAUAN TEORITIS DAN PERUMUSAN HIPOTESIS}

Ketidakpastian Lingkungan

Lingkungan merupakan hal yang sangat penting bagi suatu organisasi McLeod dan Schell, (2001). Lingkungan suatu organisasi akan berbeda dibandingkan dengan lingkungan organisasi lainnya, bergantung pada jenis dan lokasinya. Pengertian ketidakpastian lingkungan menurut Robbins dan Coulter yang dialih bahasakan oleh Sabran dan Putera (2010) adalah sebagai berikut : "Ketidakpastian lingkungan merupakan tingkat (laju) perubahan serta kompleksitas yang terjadi di lingkungan tersebut." Ketidakpastian lingkungan sebagai keterbatasan individu dalam menilai probabilitas seberapa besar keputusan yang telah dibuat akan gagal atau berhasil yang disebabkan karena kesulitan untuk memprediksi kemungkinan-kemungkinan yang akan terjadi (Kartika, 2010). Berdasarkan pengertian ketidakpastian lingkungan yang telah dikemukakan dapatdisimpulkan bahwa ketidakpastian lingkunganadalah kondisi lingkungan di luar perusahaan yangdapat terjadi dan dapat mempengaruhi aktivitas perusahaan, akan tetapisulit untuk diprediksioleh manajer. Tahyudin (2013) ketidakpastian lingkungan dapat dikelompokan menjadi tiga tipe. Adapun tiga tipe ketidakpastian lingkungan menurut Miliken, yaitu: (1) Ketidakpastian keadaan (state uncertainty), terjadi jika seorang manajer merasa bahwa lingkungan organisasinya tidak dapat di prediksi artinya seseorang tidak paham bagaimana komponen lingkungan akan mengalami perubahan. Seorang manajer dapat merasa tidak pasti terhadap tindakan apa yang harus dilakukan 
dalam menghadapi dinamika perubahan lingkungan yang relevan, seperti pertumbuhan teknologi, budaya, dan lain sebagainya. (2) Ketidakpastian pengaruh (effect uncertainty), berkaitan dengan ketidakmampuan manajer untuk memprediksi pengaruh lingkungan terhadap organisasi. Seorang manajer berada dalam ketidakpastian pengaruh bila ia merasa tidak pasti terhadap bagaimana sesuatu peristiwa tersebut berpengaruh (ke dalam) dan kapan pengaruh tersebut akan sampai pada perusahaan (waktu). (3) Ketidakpastian respon (respon uncertainty), adalah usaha memahami pilihan respon apa yang tersedia bagi manfaat organisasi dari tiap-tiap respon yang akan dilakukan. Dengan demikian, ketidakpastian respon didefinisikan sebagai ketiadaan pengetahuan tentang pilihan respon dan ketidakmampuan untuk memprediksi konsekuensi yang mungkin timbul sebagai akibat pilihan respon.

\section{Desentralisasi}

Pengertian desentralisasi menurut Garrison dan Noreen (2001) adalah sebagai berikut Desentralisasi adalah delegasi pengambilan keputusan otoritas di seluruh organisasi dengan menyediakan manajer di berbagai tingkat operasi dengan otoritas untuk membuat keputusan yang berkaitan dengan bidang tanggung jawab mereka. Menurut Simamora (2012), pengertian desentralisasi adalah sebagai berikut "Desentralisasi adalah delegasi otoritas/wewenang pengambilan keputusan kepada atasan manajemen yang lebih rendah di dalam sebuah organisasi." Berdasarkan pengertian-pengertian mengenai desentralisasi, maka dapat disimpulkan bahwa desentralisasi merupakan suatu proses pembagian tugas dan wewenang dalam hal pengambilan keputusan dan kebijakan yang menyangkut dengan cara bagaimana organisasi akan dijalankan. Desentralisasi berdampak pada meningkatnya kebutuhan terhadap karakteristik informasi sistem manajemen yang andal, hal ini disebabkan karena manajer memiliki tanggung jawab dan pengendalian aktivitas yang lebih besar sehingga membutuhkan akses yang lebih besar pula kepada informasi. Handoko (2001) Desentralisasi mempunyai nilai apabila dapat membantu organisasi mencapai tujuannya dengan efisien. Penentuan derajat desentralisasi sangat dipengaruhi oleh faktorfaktor sebagai berikut : (a) Karakteristik manjemen. (b) Ukuran dan tingkat pertumbuhan organisasi. (c) Strategi dan lingkungan organisasi. (d) Penyebaran geografis organisasi. (e) Tersedianya peralatan pengawasan yang efektif. (f) Kualitas manajer. (g) Keanakaragaman produk dan jasa. (h) Karakteristikkarakteristik organisasi lainnya, seperti biaya dan resiko yang berhubungan dengan pembuatan keputusan, sejarah pertumbuhan organisasi, kemampuan manajemen bawah, dan sebagainya. Desentralisasi diperlukan sebab adanya kondisi administratif yang semakin kompleks, begitu pula dengan tugas dan tanggung jawab, sehingga perlu pendistribusian otoritas kepada manajemen yang lebih rendah. Menurut Febriati dan Riharjo (2013), terdapat empat kunci dalam penerapan wewenang terdesentralisasi, yaitu: (1) Delegasi. (2) Wewenang. (3) Tanggung jawab. (4) Akuntabilitas. Faktor-faktor yang mempengaruhi derajat desentralisai dalam suatu organisasi, mungkin berbeda hal ini mungkin dikarenakan berbedanya divisi atau departemen organisasi atau perubahan lingkungan internal maupun eksternal. Jadi pendekatan yang paling logis yang dapat digunakan organisasi adalah dengan mengamati segala kemungkinan yang akan terjadi.

\section{Pembebanan Tugas}


Mengidentifikasi tugas-tugas atau kegiatankegiatan yang akan dilaksanakan untuk mencapai tujuan organisasi dapat disebut job designing. Sedangkan proses dalam menentukan prosedur dan kegiatan apa yang akan dilaksanakan seseorang dalam jabatannya dengan dasar job specialization. Dimana membagi tugas-tugas ke dalam komponen yang lebih kecil dengan cara sistematis (Rini, 2007). Job spesialization dapat dilakukan deengan cara : (1) Melakukan rotasi tugas. (2) Menambah tugas suatu unit. (3) Menambah tugas dan wewenang. Dalam pemberian wewenang harus sama dengan tanggung jawab. Jika beban tanggung jawab lebih besar dari wewenang maka dapat menimbulkan dampak orang tersebut akan stress, tidak tahan dan mundur dari pekerjaannya. Sebaliknya jika authority lebih besar dari tanggung jawab akan menimbulkan korupsi dan penyelewengan kekuasaan (Harahap, 2007). Langkah-langkah dalam pendelegasian wewenang : (1) Tugas dan tanggung jawab. (2) Berikan wewenang untuk menyelesaikan tugas. (3) Minta pertanggungjawaban atau accountability.

Namun dalam prakteknya, sering ditemukan kendala dalam pendelegasian wewenang, seperti: (a) Pekerjaan tidak teratur, sehingga sulit didelegasikansecara sistematis. (b) Takut pada atasan, bawahan akan mengerjakannya lebih baik sehingga akan mempengaruhi eksistensinya sebagai atasan. (c) Atasan takut kalau bawahannya tidak mampu mengerjakannya. (d) Bawahan tidak mau menerima tugas.

\section{Pelaporan Keuangan Berbasis Akrual (PP Nomor 71 Tahun 2010)}

Menurut Simanjutak (2010) menjelaskan bahwa akuntansi berbasis akrual merupakan suatu basis akuntansi yang terkait dengan pengakuan, pencatatan dan penyajian transaksi ekonomi dan peristiwa lain dalam laporan keuangan pada saat terjadinya tersebut, tanpa memperhatikan waktu kas atau setara kas diterima atau dibayarkan. Menurut Mahmudi (2011) dalam pengaplikasiannya akuntansi akrual memiliki tujuan dalam penentuan biaya pelayanan (cost of service) dan penentuan harga/tarif (pricing/charging for service). Menurut Ritonga (2010) akuntansi berbasis akrual memiliki konsep sebagai berikut: (a) Pengakuan pendapatan suatu konsep ketika perusahaan mempunyai hak melakukan penagihan atau suatu transaksi/kejadian dan yang penting adalah tentang kapan kas benarbenar diterima. (b) Pengakuan biaya pengakuan saat kewajiban sudah terjadi, namun biaya belum dibayarkan, missal utang usaha yang jatuh tempo.

Mardiasmo (2009) juga menyatakan bahwa akuntansi berbasis akrual dianggap lebih baik daripada akuntansi berbasis kas karena dianggap laporan keuangan yang disajikan lebih dapat dipercaya, lebih akurat, lebih komprehensif, dan lebih relevan untuk digunakan dalam pengambilan keputusan dari segi ekonomi, sosial, budaya, dan politik.

Dalam study nomor 14 yang diterbitkan oleh Internasional Public Sektor Accounting Standard Board (2011), mengatakan bahwa informasi yang disajikan pada akuntansi berbasis akrual dalam pelaporan keuangan memungkinkan pemangku kepentingan (stakeholder) dalam rangka : (a) Menilai akuntabilitas pengolahan seluruh sumber daya entitas serta penyebaran sumber daya tersebut. (b) Menilai kinerja, posisi keuangan dan arus dari suatu entitas. (c) Pengambilan keputusan mengenai penyediaan sumber daya, atau melakukan bisnis dengan suatu entitas.

\section{Perumusan Hipotesis}




\section{Pengaruh ketidakpastian ligkungan terhadap pelaporan keuangan berbasis akrual.}

Ketidakpastian lingkungan adalah situasi dimana seseorang terkendala untuk memprediksi keadaan sekitar, sehingga sulit untuk mengetahui gagal atau berhasil keputusan yang dibuat. Menurut Mardiyah dan Gudono (2001) ketidakpastian lingkungan adalah kondisi lingkungan ekternal yang dapat mempengaruhi operasionalisasi perusahaan. Sedangkan Tjahjadi (2011) ketidakpastian lingkungan didefinisikan sebagai faktor-faktor lingkungan yang dihadapi oleh organisasi dan berpotensi menggangu kinerja organisasi bila organisasi tidak mampu beradaptasi dengan baik terhadap laju perubahan maupun dinamikanya, yang terdiri dari faktor-faktor tingkat perubahan regulasi, tingkat perubahan teknologi informasi, tingkat perubahan pasar dan persaingan. Ketidakpastian lingkungan yang dihadapi merupakan salah satu faktor yang mempengaruhi keberhasilan perusahaan. Semakin tinggi kemampuan dalam memprediksi maka semakin rendah tingkat ketidakpastian lingkungan yang dihadapi. Ketidakpastian lingkungan yang tinggi diidentifikasi sebagai faktor penting karena kondisi demikian dapat menyulitkan perencanaan dan pengendalian. Perencanaan menjadi bermasalah dalam situasi operasi yang tidak pasti karena tidak terprediksinya kejadian dimasa mendatang. Penelitian sebelumnya Asroel (2016), Lubis (2017), Indrayani, et al. (2017) menemukan bahwa ketidakpastian lingkungan berpengaruh terhadap transparansi pelaporan keuangan. Untuk mengatasi ketidakpastian lingkungan maka dibutuhkan informasi akuntansi manajemen. Kondisi tersebut menunjukkan semakin tinggi tingkat ketidakpastian lingkungan menyebabkan manajer merasa tidak memiliki informasi yang cukup untuk memprediksi masa depan secara akurat. Pengendalian terhadap aktivitas perusahaan juga sulit dilakukan dalam suasana yang tidak pasti. Kesulitan yang disebabkan oleh ketidakpastian lingkungan yang dirasakan oleh para manajer baik menyangkut aktivitas perencanaan maupun pengendalian dapat dikurangi dengan pendelegasian wewenang (desentralisasi) dan pemberian informasi lingkup luas (Muslichah, 2002). Organisasi yang sukses akan selalu beradaptasi dengan perubahan perubahan lingkungannya dan secara proaktif merubah lingkungannya. Organisasi harus mengelola ketidakpastian lingkungan untuk menjadi efektif. Dengan demikian dapat dikatakan bahwa tingkat ketidakpastian lingkungan yang semakin tinggi mempengaruhi menurunnya pelaporan keuangan berbasis akrual. Berdasarkan penjelasan diatas, maka penelitian ini bermaksud untuk menguji ketidakpastian lingkungan terhadap pelaporan keuangan berbasis akrual.

$\mathrm{H}_{1}$ : Ketidakpastian lingkungan berpengaruh negatif terhadap pelaporan keuangan berbasis akrual.

\section{Pengaruh desentralisasi terhadap pelaporan keuangan berbasis akrual.}

Menurut Hansen dan Mowen (2001) desentralisasi adalah praktek pendelegasian wewenang pengambilan keputusan kepada jenjang yang lebih rendah. Simamora (2005) desentralisasi adalah otoritas atau wewenang pengembalian keputusan kepada jajaran manajemen yang lebih rendah kedalam sebuah organisasi. Mendelegasikan wewenang dari top manajemen kepada unit organisasi yang menjadi bawahannya merupakan salah satu cara yang sering digunakan dalam pengendalian kegiatan organisasi. Desentralisasi dengan memberikan pertanggungjawaban untuk berbagai tugas bagi manajer tingkat bawah 
merupakan mekanisme organisasi yang dapat menjamin bahwa tugas-tugas dapat dilaksanakan dan tujuan organisasi akan dapat dicapai. Dari penelitian yang dilakukan Desmiyanti (2010) dan Ingkiriwang (2013) desentralisasi berpengaruh terhadap kinerja manajerial. Desentaralisasi dalam bentuk pendistribusian otoritas pada manajemen yang lebih rendah diperlukan, karena untuk mempermudah dan semakin kompleks kondisi administratif, tugas dan tanggung jawab. Dengan pendelegasian wewenang maka akan membantu meringankan beban tugas manajemen yang lebih tinggi. Tingkat desentralisasi yang tinggi merupakan bentuk yang tepat untuk menghadapi peningkatan ketidakpastian sehingga menunjang pencapaian kinerja manajerial yang lebih baik. Melalui desentralisasi suatu organisasi mampu menyediakan manajernya dengan tanggung jawab dan pengendalian yang lebih besar terhadap aktivitas dan juga akses yang lebih besar terhadap informasi yang dibutuhkan. Adanya desentralisasi ini akan menyebabkan para manajer yang dikenai limpahan wewenang membutuhkan karakteristik sistem akuntansi manajemen yang andal agar dapat menyediahkan kebutuhan informasi yang tepat dan relevan dalam laporan keuangan berbasis akrual. Hal ini terjadi karena dalam sistem desentralisasi manajer tidak hanya menjalankan tugas atas perintah atasanya saja, tetapi harus juga dapat mengambil keputusan yang mana keputusan tersebut dapat memberikan keuntungan bagi instansi/perusahaan yang mereka pimpin. Berdasarkan penjelasan diatas, maka penelitian ini bermaksud untuk menguji desentralisasi terhadap pelaporan keuangan berbasis akrual.

$\mathrm{H}_{2}$ : Desentralisasi berpengaruh positif terhadap pelaporan keuangan berbasis akrual.
Pengaruh pembebanan tugas terhadap pelaporan keuangan berbasis akrual.

Pembebanan tugas adalah kegiatan seorang atasan menugaskan bawahannya untuk mengerjakan bagian daripada tugas manajer yang bersangkutan, dan pada waktu yang bersamaan memberikan kekuasaan kepada bawahan tersebut sehingga bawahan itu dapat mempertanggung jawabkan tugas yang didelegasikan kepadanya. Dalam penelitian yang dilakukan Rini (2007) pembebanan tugas tidak mempunyai pengaruh yang signifikan terhadap akuntabilitas kinerja dinas. Pembebanan tugas ini diharapkan dapat membuat tugas manajer lebih mudah karena telah didelegasikan kepada bawahannya. Memberikan pertanggungjawaban berarti memberikan laporan bagaimana seseorang melaksanakan tugas-tugasnya dan bagaimana dia memakai wewenang yang diberikan kepadanya. Pertanggungjawaban kepada pemerintahan pusat dan pertanggungjawaban kepada masyarakat luas. Berdasarkan penjelasan diatas, maka penelitian ini bermaksud untuk menguji pembeban tugas yang diberikan berpengaruh terhadap pelaporan keuangan berbasis akrual.

$\mathrm{H}_{3}$ : Pembebanan tugas berpengaruh negatif terhadap pelaporan keuangan berbasis akrual.

\section{METODE PENELITIAN / METHODS Jenis Penelitian}

Metode penelitian ini menggunakan pendekatan kuantitatif. Jenis penelitian bersifat explanatory research, karena didalam penelitian ini bertujuan untuk membuktikan hipotesis serta memberikan penjelasan secara empiris untuk mengkaji hasil penelitian berdasarkan teori yang ada. Menurut Arikunto (2010) populasi adalah keseluruhan dari subjek penelitian. Sedangkan menurut Sugiyono (2014) populasi adalah wilayah generalisasi, 
objek/subjek yang mempunyai kualitas dan karakteristik tertentu yang ditetapkan oleh peneliti untuk dipelajari dan kemudian ditarik kesimpulannya.

\section{Teknik Pengambilan Sampel}

Menurut Arikunto (2010) sampel adalah sebagian atau wakil populasi yang diteliti. Sedangkan menurut Sugiyono (2014) sampel adalah bagian dari jumlah dan karakteristik yang dimiliki oleh populasi tersebut. Sampel pada penelitian ini adalah pemerintah daerah Kabupaten Sidoarjo. Teknik pengambilan sampel yang digunakan adalah metode purposive sampling. Menurut Sugiyono (2014) purposive sampling adalah teknik untuk menentukan sampel penelitian dengan beberapa pertimbangan tertentu yang bertujuan agar data yang diperoleh nantinya bisa lebih representatif. Sampel dalam penelitian ini yaitu Pejabat Penatausahaan Keuangan Organisasi Pemerintahan Daerah (PPK-OPD) dan Pejabat Penatausahaan Keuangan Daerah (PPKD) diwilayah Kabupaten Sidoarjo. Adapun kriteria yang digunakan dalam penelitian ini meliputi: (1) Pegawai yang berkedudukan sebagai Pejabat Penatausahaan Keuangan (PPK) dan Pejabat Penatausahaan Keuangan Daerah (PPKD). (2) Memiliki masa kerja minimal 3 (Tiga) Tahun.

\section{Teknik Pengumpulan Data}

Dalam penelitian ini teknik pengumpulan data yang mengunakan data kuesioner.

Menurut Sugiyono (2014), kuesioner merupakan teknik pengumpulan data yang efisien apabila peneliti tahu dengan siapa variabel akan diukur dan tahu apa yang bisa diharapkan dari responden. Kuesioner dapat berupa pertanyaan-pertanyaan tertutup atau terbuka, dapat diberikan kepada responden secara langsung atau dikirim melalui pos atau internet. Untuk menentukan skor pilihan jawaban responden menggunakan skala Likert. Dikemukakan Sugiyono (2014) bahwa skala Likert digunakan untuk mengukur sikap, pendapat, dan persepsi seseorang atau sekelompok orang tentang fenomena sosial. Kuesioner diberikan kepada Pejabat Penatausahaan Keuangan Organisasi Pemerintah Daerah (PPK-OPD) dan Pejabat Penatausahaan Keuangan Daerah (PPKD) di Kabupaten Sidoarjo.

\section{Pengukuran Variabel}

Tabel 1

Pengukuran Variabel

\begin{tabular}{ccccc}
\hline Variabel & Indikator Variabel & Butir Pertanyaan & $\begin{array}{c}\text { Teknik } \\
\text { Pengukuran }\end{array}$ & Sumber \\
\hline $\begin{array}{c}\text { Ketidakpastian } \\
\text { Lingkungan }\end{array}$ & 1. Keadaan & $\begin{array}{c}\text { 1. Lingkungan internal } \\
\text { 2. Lingkungan } \\
\text { 3. Eksternal }\end{array}$ & Interval & $\begin{array}{c}\text { Asroel } \\
(2016)\end{array}$ \\
\hline
\end{tabular}




\begin{tabular}{|c|c|c|c|c|}
\hline & 3. Respon & 4. Tanggapan & & \\
\hline Desentralisasi & $\begin{array}{l}\text { 1. Pengembangan } \\
\text { 2. Perencanaan } \\
\text { Kebijakan } \\
\text { 3. Penentuan }\end{array}$ & $\begin{array}{l}\text { 1. Tingkat SDM karyawan } \\
\text { 2. Investasi } \\
\text { 3. Alokasi anggaran } \\
\text { 4. Prioritas program }\end{array}$ & Interval & Rini (2007) \\
\hline Pembebanan & 1. Beban kinerja & 1. Integritas kinerja & & \\
\hline Tugas & $\begin{array}{l}\text { 2. Pemahaman } \\
\text { pekerjaan } \\
\text { 3. Beban tugas }\end{array}$ & $\begin{array}{l}\text { 2. Pemahaman dan rutinitas } \\
\text { yang berulang-ulang } \\
\text { 3. Rutinitas tugas yang } \\
\text { dikerjakan }\end{array}$ & Interval & Rini (2007) \\
\hline $\begin{array}{l}\text { Pelaporan } \\
\text { Keuangan }\end{array}$ & $\begin{array}{c}\text { 1. Pemahaman } \\
\text { instansi }\end{array}$ & $\begin{array}{l}\text { 1. Kemampuan } \\
\text { 2. Ketepatan waktu }\end{array}$ & & \\
\hline Berbasis Akrual & $\begin{array}{l}\text { 1. Pemahaman } \\
\text { aparatur } \\
\text { 3. Komitmen } \\
\text { pemerintah } \\
\text { 3. Faktor } \\
\text { penghambat }\end{array}$ & $\begin{array}{l}\text { 2. Pengetahuan dan } \\
\text { pemahaman } \\
\text { 4. Pemenuhan komitmen } \\
\text { 5. Sosialisasi } \\
\text { 4. Pendidikan dan } \\
\text { pengalaman } \\
\text { 5. Fasilitas dan sistem }\end{array}$ & Interval & $\begin{array}{l}\text { Biduri } \\
(2013)\end{array}$ \\
\hline
\end{tabular}

\section{Analisis Regresi Linear Berganda}

Pengujian hipotesis menggunakan analisis regresi berganda (multiple regression). Dalam analisis regresi berganda selain mengukur hubungan antara dua variabel atau lebih, juga menunjukan arah hubungan antar variabel dependen dengan variabel independen. Variabel dependen diasumsikan random berarti mempunyai distribusi probabilistic, sedangkan variabel independen diasumsikan memiliki nilai tetap Ghozali (2005). Adapun persamaan yang digunakan dalam hipotesis penelitian ini adalah :

$\mathbf{P K B A}=\alpha+b_{1} K L+b_{2} D S+b_{3} P T+e$

Keterangan :

$\begin{array}{ll}\text { PKBA } & =\text { Laporan Keuangan Berbasis } \\ & \text { Akrual } \\ \alpha & =\text { konstanta } \\ \mathrm{b}_{1} & =\text { konfisien regresi parsial } \mathrm{X}_{1} \\ \mathrm{KL} & =\text { Ketidakpastian lingkungan } \\ \mathrm{b}_{2} & =\text { konfisien regresi parsial } \mathrm{X}_{2} \\ \mathrm{DS} & =\text { Desentralisasi } \\ \mathrm{b}_{3} & =\text { konfisien regresi parsial } \mathrm{X}_{3} \\ \mathrm{PT} & =\text { Pembebanan tugas } \\ \mathrm{e} & =\text { error }\end{array}$

\section{Uji Hipotesis (Uji t)}

Uji $t$ dilakukan pada dasarnya untuk mengetahui apakah variabel bebas mempunyai pengaruh secara individual atau secara parsial terhadap variabel terikat (Kuncoro, 2007). Pengujian dilakukan dengan menggunakan significance level 0,05 $(\alpha=5 \%)$. Untuk menguji hipotesis dilakukan dengan cara: (1) Jika nilai signifikan $\mathrm{t}>0,05$ maka hipotesis ditolak. Hal ini berarti bahwa secara parsial variabel independen tersebut tidak mempunyai pengaruh yang signifikan terhadap variabel dependen. (2) Jika nilai signifikan $\mathrm{t} \leq 0,05$ maka hipotesis diterima. Hal ini berarti bahwa secara parsial variabel independen tersebut mempunyai pengaruh yang signifikan terhadap variabel dependen.

\section{HASIL PENELITIAN DAN DISKUSI / RESULTS AND DISCUSSION}

Pengujian ini pada dasarnya menunjukkan seberapa jauh pengaruh satu variabel ketidakpastian lingkungan, desentralisasi, dan pembebanan tugas secara 
individual dalam menerangkan variasivariabel pelaporan keuangan berbasis akrual. Pengujian dilakukan dengan menggunakansignificance level 0,05 $(\alpha=5 \%)$. Penerimaan atau penolakan hipotesis dilakukan dengan kriteria sebagai berikut: (1) Jika nilai signifikansi $t>0,05$ maka hipotesis ditolak. (2) Jika nilai signifikansi $\mathrm{t} \leq 0,05$ maka hipotesis diterima. Hasil dari Uji t yang tampak pada Tabel 17.

Tabel 17

Hasil Uji $\mathbf{t}$

\begin{tabular}{|c|c|c|c|c|c|c|}
\hline \multicolumn{7}{|c|}{ Coefficients $^{a}$} \\
\hline & \multirow[b]{2}{*}{ Model } & \multicolumn{2}{|c|}{$\begin{array}{c}\text { Unstandardized } \\
\text { Coefficients }\end{array}$} & \multirow{2}{*}{$\begin{array}{c}\text { Standardized } \\
\text { Coefficients } \\
\text { Beta }\end{array}$} & \multirow[b]{2}{*}{$\mathrm{t}$} & \multirow[b]{2}{*}{ Sig. } \\
\hline & & B & Std. Error & & & \\
\hline \multirow[t]{4}{*}{1} & (Constant) & 16.476 & 4.105 & & 4.013 & .000 \\
\hline & KL & .284 & .111 & .213 & 2.557 & .012 \\
\hline & DS & 1.207 & .106 & .807 & 11.385 & .000 \\
\hline & PT & -.124 & .066 & -.155 & -1.863 & .066 \\
\hline
\end{tabular}

a. Dependent Variable: EP

Sumber: Data Primer 2018, diolah.

Berdasarkan hasil uji t pada Tabel 17, dapat diperoleh : (1) Pengujian pengaruh ketidakpastian lingkungan terhadap laporan keuangan berbasis akrua menghasilkan nilai signifikansi 0,012 atau nilai signifikansi < 0,05 , dengan arah positif dan signifikan terhadap pelaporan keuangan berbasis akrual, hal ini sesuai dengan hipotesis yang dirumuskan yang menyatakan bahwa ketidakpastian lingkungan berpengaruh positif terhadap pelaporan keuangan berbasis akrual, dengan demikian hipotesis pertama ditolak. (2) Pengujian pengaruh desentralisasi terhadap pelaporan keuangan berbasis menghasilkan nilai signifikansi 0,000 atau nilai signifikansi $<0,05$, dengan arah positif terhadap pelaporan keuangan berbasis akrual, hal ini sesuai dengan hipotesis yang dirumuskan yang menyatakan bahwa desentralisasiberpengaruh positif dan signifikan terhadap pelaporan keuangan berbasis akrual, dengan demikian hipotesis kedua diterima. (3) Pengujian pengaruh pembebanan tugasterhadap pelaporan keuangan berbasis akrual menghasilkan nilai signifikansi 0,066 atau nilai signifikansi > 0,05 , dengan arah negatif dan tidak signifikan terhadap pelaporan keuangan berbasis, hal ini sesuai dengan hipotesis yang dirumuskan yang menyatakan bahwa pembebanan tugas berpengaruh negatif terhadap pelaporan keuangan berbasis akrual, dengan demikian hipotesis ketiga diterima.

\section{Pengaruh Ketidakpastian Lingkungan Terhadap Pelaporan Keuangan Berbasis Akrual.}

Hipotesis penelitian yang pertama menyatakan bahwa ketidakpastian lingkungan berpengaruh positif terhadap pelaporan keuangan berbasis akrual. Berdasarkan hasil pengujian menunjukkan bahwa $\mathrm{H}_{1}$ ditolak. Hasil penelitian ini sejalan dengan penelitian yang dilakukan oleh Asroel (2016); Lubis (2017); Indrayani, et al. (2017), dengan hasil pengujiannya yang menyatakan bahwa semakin tinggi tingkat ketidakpastian lingkungan menyebabkan manajer merasa semakin tidak memiliki informasi yang cukup untuk memprediksi 
masa depan secara akurat. Sistem akuntansi manajemen yang handal akan memudahkan penyediaan informasi yang tepat waktu dan relevan, dimana seorang manajer memiliki kebutuhan informasi yang berbeda-beda, dengan demikian dapat dikatakan bahwa tingkat ketidakpastian lingkungan akan mempengaruhi tingkat ketersediaan informasi sistem akuntansi manajemen. Ketidakpastian dapat diartikan sebagai rasa ketidakmampuan individu dalam memprediksi lingkungannya secara tepat. Ketidakpastian lingkungan yang dihadapi merupakan salah satu faktor yang mempengaruhi keberhasilan perusahaan. Semakin tinggi kemampuan manajer dalam memprediksi, maka semakin rendah tingkat ketidakpastian lingkungan yang dihadapi. Ketidakpastian lingkungan yang tinggi diidentifikasi sebagai faktor penting karena kondisi demikian dapat menyulitkan dalam perencanaan dan pengendalian, perencanaan menjadi bermasalah dalam situasi operasi yang tidak pasti karena tidak terprediksinya kejadian dimasa yang akan datang. Seorang manajer dapat merasa tidak dapat memprediksi secara pasti terhadap tindakan apa yang harus dilakukan dalam menghadapi dinamika para pemasok, pesaing, pelanggan, konsumen dan lain sebagainya, atau manajer merasa tidak dapat memprediksi secara pasti terhadap kemungkinan perubahan lingkungan yang relevan, seperti perubahan teknologi, budaya, demografi dan lain-lain. Ketidakpastian pengaruh (effect uncertainty) berkaitan dengan ketidakmampuan seorang manajer untuk memprediksi pengaruh lingkungan terhadap organisasi. Ketidakpastian pengaruh ini meliputi sifat, kedalaman, dan waktu. Seorang manajer berada dalam kondisi ketidakpastian pengaruh, bila ia merasa tidak pasti terhadap bagaimana suatu peristiwa berpengaruh terhadap organisasi (sifat), seberapa jauh peristiwa tersebut berpengaruh (kedalaman) dan kapan pengaruh tersebut akan sampai pada organisasi (waktu). Ketidakpastian pengaruh atas peristiwa yang terjadi pada masa yang akan datang akan menjadi lebih menonjol jika ketidakpastian keadaan lingkungan sangat tinggi di masa yang akan datang. Lingkungan akan mempengaruhi kehidupan organisasi, karena di dalam lingkungan organisasi yang stabil proses perencanaan dan pengendalian tidak banyak menghadapi masalah, namun dalam kondisi yang tidak pasti proses perencanaan dan pengendalian akan menjadi lebih sulit dan banyak menghadapi masalah karena kejadian-kejadian yang akan datang sulit diperkirakan (Muntu, 2006). Konsep ketidakpastian, tidak berhubungan dengan lingkungan fisik itu sendiri, tetapi dengan pengetahuan individu dan persepsi terhadap lingkungannya. Dalam ketidakpastian lingkungan yang tinggi, informasi merupakan komoditi yang sangat berguna dalam proses kegiatan perencanaan dan kontrol dalam suatu organisasi. Sistem akuntansi manajemen yang andal akan memudahkan penyediaan informasi yang tepat waktu dan relevan, dimana manajer memiliki kebutuhan informasi yang berbeda-beda. Ketidakpastian lingkungan dalam hal ini adalah kondisi dimana OPD mengalami perubahan dalam lingkungannya yang disebabkan adanya pengaruh dari luar OPD, seperti sering terjadinya perubahan peraturan, tidak matvhnya atara peraturan yang satu dengan yang lain, terjadinya mutasi staf OPD yang cepat dan, lain sebagainya. OPD dituntut untuk dapat menyesuaikan diri dengan kondisi lingkungan yang ada, baik dalam praktik maupun operasionalnya.

\section{Pengaruh Desentralisasi Terhadap Pelaporan Keuangan Berbasis Akrual. \\ Hipotesis penelitian yang kedua menyatakan bahwa desentralisasi}


berpengaruh positif terhadap pelaporan keuangan berbasis akrual. Berdasarkan hasil pengujian menunjukkan bahwa $\mathrm{H}_{2}$ diterima. Hasil penelitian ini sejalan dengan penelitian yang dilakukan oleh Desmiyanti (2010) dan Ingkiriwang (2013), dengan hasil pengujiannya yang menyatakan bahwa desentaralisasi dalam bentuk pendistribusian otoritas pada manajemen yang lebih rendah diperlukan karena semakin kompleks kondisi administratif, tugas dan tanggung jawab. Dengan pendelegasian wewenang maka akan membantu meringankan beban tugas manajemen yang lebih tinggi. Tingkat desentralisasi yang tinggi merupakan bentuk yang tepat untuk menghadapi tingkat ketidakpastian sehingga menunjang pencapaian kinerja manajerial yang lebih baik. Tingkat pendelegasian menunjukkan seberapa jauh manajemen yang lebih tinggi mengijinkan manajemen yang lebih rendah untuk membuat kebijakan secara independen artinya pendelegasian atau pertanggungjawaban yang diberikan kepada manajemen yang lebih rendah (subordinate) dalam kaitannya dengan otoritas pembuatan keputusan (decision making) dan desentralisasi memerlukan tanggung jawab terhadap aktivitas subordinate tersebut. Otoritas disini memberikan pengertian sebagai hak untuk menentukan penugasan, sedangkan tanggung jawab adalah kewajiban untuk mencapai tugas yang telah ditetapkan. Adanya kondisi desentralisasi menyebabkan manajer memiliki peran yang lebih besar dalam pembuatan keputusan dan pengimplementasiannya, serta lebih bertanggung jawab terhadap aktivitas unit kerja yang dipimpinnya. Desentralisasi juga akan menyebabkan para manajer yang dikenai limpahan wewenang membutuhkan informasi yang berkualitas serta relevan guna mendukung kualitas keputusan. Organisasi yang desentralisasi akan menjadi lebih efektif apabila mendukung pengguna informasi untuk pengambilan keputusan. Desentralisasi berdampak pada meningkatnya kebutuhan terhadap karakteristik informasi sistem manajemen yang andal, hal ini disebabkan karena manajer memiliki tanggung jawab dan pengendalian aktivitas yang lebih besar sehingga membutuhkan akses yang lebih besar pula kepada informasi. Mendelegasikan wewenang dari top manajemen kepada unit organisasi yang menjadi bawahannya merupakan salah satu cara yang sering digunakan dalam pengendalian kegiatan organisasi. Desentralisasi dengan memberikan pertanggungjawaban untuk berbagai tugas bagi manajer tingkat bawah merupakan mekanisme organisasi yang dapat menjamin bahwa tugas-tugas dapat dilaksanakan dan tujuan organisasi akan dapat dicapai. Manajer pusat pertanggungjawaban (unit organisasi) bisa diberikan target yang jelas tentang rentang tugasnya dan bertanggung jawab atas segala aspek pertanggung jawabannya. Organisasi harus menyerahkan sebagian wewenang pengambilan keputusannya kepada manajer yang lebih rendah tingkatannya. Makin besar kadar penyerahan ini, makin besar desentralisasi yang terdapat dalam organisasi yang bersangkutan.

\section{Pengaruh Pembebanan Tugas Terhadap Pelaporan Keuangan Berbasis Akrual.}

Hipotesis penelitian yang ketiga menyatakan bahwa pembebanan tugas berpengaruh negatif terhadap pelaporan keuangan berbasis akrual. Berdasarkan hasil pengujian menunjukkan bahwa $\mathrm{H}_{3}$ diterima. Hasil penelitian ini sejalan dengan penelitian yang dilakukan oleh Rini (2007), dengan hasil pengujiannya yang menyatakan bahwa pembebanan tugas ini diharapkan dapat membuat tugas manajer lebih mudah karena 
telah didelegasikan kepada bawahannya, memberikan pertanggungjawaban berarti memberikan laporan bagaimana seseorang melaksanakan tugas-tugasnya dan bagaimana dia memakai wewenang yang diberikan kepadanya. Pembebanan tugas adalah kegiatan seorang atasan untuk menugaskan bawahannya untuk mengerjakan bagian daripada tugas manajer yang bersangkutan, dan pada waktu yang bersamaan memberikan kekuasaan kepada bawahan tersebut sehingga bawahan itu dapat mempertanggung jawabkan hal-hal yang didelegasikan kepadanya. Mengidentifikasi tugas-tugas atau kegiatan-kegiatan yang akan dilaksanakan untuk mencapai tujuan organisasi dapat disebut job designing. Sedangkan proses dalam menentukan prosedur dan kegiatan apa yang akan dilaksanakan seseorang dalam jabatannya dengan dasar job specialization. Dimana membagi tugas-tugas ke dalam komponen yang lebih kecil dengan cara sistematis. Pemberian wewenang harus sama dengan tanggung jawab. Jika beban tanggung jawab lebih besar dari wewenang maka dapat menimbulkan dampak orang tersebut akan stress, tidak tahan dan mundur dari pekerjaannya. Sebaliknya jika authority lebih besar dari tanggung jawab akan menimbulkan korupsi dan penyelewengan kekuasaan.

\section{KESIMPULAN, SARAN DAN KETERBATASAN PENELITIAN Simpulan}

Berdasarkan hasil penelitian dan pembahasan pada bab sebelumnya, maka peneliti dapat menarik simpulan sebagai berikut : (1) Hasil penelitian menunjukkan bahwa ketidakpastian lingkungan berpengaruh signifikan terhadap laporan keuangan berbasis akrual dengan arah koefisien positif. Hal ini menunjukan semakin tinggi tingkat ketidakpastian lingkungan menyebabkan manajer merasa tidak memiliki informasi yang cukup untuk memprediksi masa yang akan detang secara akurat. Kondisi ketidakpastian yang tinggi, informasi menjadi komoditi yang sangat berguna sekali dalam proses kegiatan perencanaan dan control dalam suatu organisasi. Sistem akuntansi manajemen yang handal akan membantu dalam memudahkan penyediaan informasi yang tepat waktu dan relevan, dimana para manajer memiliki kebutuhan informasi yang berbeda-beda, dengan demikian dapat dikatakan bahwa tingkat ketidakpastian lingkunganakan mempengaruhi tingkat ketersediaan informasi sistem akuntansi manajemen. (2) Hasil penelitian menunjukkan bahwa desentralisasi berpengaruh signifikan terhadap pelaporan keuangan berbasis akrual dengan arah koefisien positif. Hal ini menunjukkan desentaralisasi dalam bentuk pendistribusian otoritas pada manajemen yang lebih rendah diperlukan karena semakin kompleks kondisi administratif, tugas dan tanggungjawab. Dengan pendelegasian wewenang maka akan membantu meringankan beban tugas manajemen yang lebih tinggi. Tingkat desentralisasi yang tinggi merupakan bentuk yang tepat untuk menghadapi dan solusi dalam peningkatan ketidakpastian sehingga menunjang pencapaian kinerja manajerial yang lebih baik. (3) Hasil penelitian menunjukkan bahwa pembebanan tugas berpengaruh terhadap pelaporan keuangan berbasis akrual dengan arah koefisien negatif. Hal ini menunjukkan pembebanan tugas ini diharapkan dapat membuat tugas manajer lebih mudah karena telah didelegasikan kepada bawahannya, memberikan pertanggungjawaban berarti memberikan laporan bagaimana seseorang melaksanakan tugas-tugasnya dan bagaimana dia memakai wewenang yang diberikan kepadanya, 
kegiatan seorang atasan untuk menugaskandan memberikan otoritas kepada bawahannya untuk mengerjakan bagian dari pada tugas manajer yang bersangkutan, dan pada waktu yang bersamaan memberikan kekuasaan kepada bawahan tersebut sehingga bawahan itu dapat mempertanggungjawabkan hal-hal yang didelegasikan kepadanya.

\section{Saran}

Berdasarkan pembahasan serta simpulan yang telah dikemukakan tentang pengaruh ketidakpastian lingkungan, desentralisasi, dan pembebanan tugas terhadap pelaporan keuangan berbasis akrual, maka saran yang dapat diajukan adalah sebagai berikut : (1) Bagi OPD di Kabupaten Sidoarjo, untuk selalu memperhatikan lingkungan kerja yang berubah sangat cepat dan dinamis, sehingga Pemerintah Kabupaten Sidoarjo sebaiknya selalu mengamati dan menyikapi perubahan lingkungan tersebut. (2) Bagi OPD di Kabupaten Sidoarjo, dengan adanya desentralisasi pad organisasi merupakan pilihan yang tepat dan sebaiknya dapat terus ditingkatkan pelaksanaannya. Hal ini dikarenakan model pendelegasian wewenang dengan pendekatan desentralisasi akan mempercepat pengambilan keputusan. (3) Bagi OPD di Kabupaten Sidoarjo perlu memperhatikan pembebanan tugas kepada para pegawainya, karena pemberian tanggung jawab harus sesuai dengan wewenangnya. Jika beban tanggungjawab lebih besar dari wewenang maka dapat menimbulkan dampak negatif, misalnya munculnya stress, tidak tahan atau mundur dari pekerjaannya.

\section{DAFTAR PUSTAKA / BIBLIOGRAPHY}

Arih, T.N, S. Rahayu dan A. Nurbaiti. 2017. Analisis Faktor-Faktor Yang Mempengaruhi Implementasi Standar Akuntansi "Pemerintah" Berbasis Akrual Pada Pemerintahan Kota Bandung. Jurnal Manajemen Indonesia 17(1)
Arikunto, S. 2010. Prosedur Penelitian Suatu Pendekatan Praktik. Jakarta: Rineka Cipta.

Asroel, R.B.S. 2016. Pengaruh Akuntabilitas, Ketidakpastian Lingkungan, Komitmen Pimpinan dan Pengendalian Internal Terhadap Penerapan Transparansi Pelaporan Keuangan (Studi Empiris Pada SKPD Provinsi Riau). JOM Fekon Vol. 1.

Azman T. 2015. Analisis Komitmen Organisasi, Kesiapan Sumberdaya Manusia, Infrastruktur Serta Sistem Informasi Dalam Menerapkan Standar Akuntansi Pemerintah Berbasis Akrual (Studi Pada Pemerintah Kabupaten Kepulauan Meranti). Jurnal SOROT 10(1).

Biduri, S. dan D.D.O. Rini. 2016. Implementasi Accrual Accounting: Perspektif Analisa SWOT (Studi Kasus Pada Pemerintah Kabupaten Sidoarjo). Proseding.

Carr, Jered. B dan S. Brower Ralph, 2000, Principled opportunism: Evidence from the Organizational Middle. Public Administration Quarterly (Spring), pp. 109-138,

http://www.jstor.org/stable/40861799.

Diakses pada 20 Januari 2014.

Chenhall, R. H. 2004. The Role of Cognitif and Affective Conflict in Early Implementation ofActivity-Based Cost Management. Behavioral Reaserch in Accounting 16:19

Damayanti, P.E, E. Sujana, dan D.N.S. Werastuti. 2015. Pengaruh Karakteristik Informasi Sistem Akuntansi Manajemen (SAM), Desentralisasi, dan Ketidakpastian Lingkungan Terhadap Kinerja Manajerial (Studi Empiris Pada Hotel Se-Kabupaten Buleleng). e-Jurnal $3(1)$.

Dewi, L.D.S, G.A. Purnamawanti, dan N.T. Herawati. 2017. Pengaruh Kualitas Sumber Daya Manusia, Komitmen Organisasi, dan Sistem Pengendalian Intern Terhadap Keberhasilan Penerapan SAP Berbasis Akrual (Studi Empiris Pada SKPD Kabupaten Bangil). e-Jurnal S1 Ak. Universitas Pendidikan Ganesha $7(1)$.

Desmiyanti. 2010. Pengaruh Desentralisasi Ketidakpastian Lingkungan dan Sistem Akuntansi Manajemen Terhadap Kinerja Manajerial. Pekbis Jurnal 2(3). November: 346-354. 
Dwirandra, A.A.N.B. 2006. Pengaruh Interaksi Ketidakpastian Lingkungan, Desentralisasi, Dan Agregat Informasi Akuntansi Manajemen Terhadap Kinerja Manajerial. Jurnal Ilmiah Akuntansi dan Bisnis.

Febrianti, D dan Riharjo, I. B. 2013. Pengaruh Partisipasi Anggaran, Desentralisasi, Komitmen Organisasi dan Ketidakpastian Lingkungan terhadap Kinerja Manajerial Pada Pemerintahan Kota Surabaya. Jurnal Ilmu dan Riset Akuntansi. Vol.1 No.1. Hal 108-121.

Fitrizal, R. 2017. Pengaruh Kualitas Sumber Daya Manusia, Sistem Informasi dan Komitmen Organisasi terhadap Implementasi Sistem Akuntansi Pemerintah Berbasis Akrual (Studi Empiris pada SKPD Kabupaten Pesisir Selatan).

Garrison, H. Ray dan E.W. Noreen. 2001. Akuntansi Manajerial. Jakarta : Salemba Empat.

Halim, A. dan Bambang S. 2000. Akuntansi Manajemen. Yogyakarta: BPFE.

Harahap, 2007, Analisis Kritis Atas Laporan Keuangan, edisi Pertama, cetakan ketiga, Penerbit : Raja Grafindo Persada, Jakarta.

Hariadi, B. (2005). Strategi Manajemen. Jakarta : Bayumedia Publishing.

Handoko, T.H. 2001. Manajemen Personalia dan Sumberdaya Manusia. Edisi Kedua. BPFE, Yogyakarta.

Herdiansyah, S. 2012. Pengaruh Karakteristik Informasi Sistem Akuntansi Manajemen Dengan Desentralisasi Terhadap Kinerja Manajerial Dengan Ketidakpastian Lingkungan Sebagai Variabel Moderating. Jurnal Akuntansi. Universitas Diponogoro.

Ingkiriwang, O.F. 2013. Pengaruh Desentralisasi dan Sistem Akuntansi Manajemen Terhadap Kinerja Manjer Dealar Di Manado. Jurnal EMBA 1(3):818-825.

Inrayani, H. H. Wulandari dan D. Miftah. 2017. Pengaruh Tekanan Ekternal, Ketidakpastian Lingkungan, dan Komitmen Terhadap Transparansi Pelaporan Keuangan Dengan Religiusitas Sebagai Variabel Moderating Pada PTKI Kota Pekan Baru. Jurnal Al-Iqtishad, Edisi 12. Vol. 1.
Jensen, Michael C. dan Meckling. William H., 1976, "Thery of The Firm: Managerial Behavior, Agency Cost, and Owners

Kartika, A. 2010. Pengaruh Komitmen Organisasi dan Ketidakpastian Lingkungan dalam Hubungan antara Partisipasi Anggaran dengan Senjangan Anggaran. Kajian Akuntansi 2(1).

Kristiawati, E. 2015. Faktor-Faktor Yang Mempengaruhi Keberhasilan Penerapan Akuntansi Berbasis Akrual Pada Pemerintahan Daerah Kalimantan Barat. Jurnal Akuntabilitas 8(3) Desember: 171-190.

Lamosini, S. 2016. Analisis Penerapan Standar Akuntansi Berbasis Akrual Pada Pemerintahan Tomohon. Jurnal EMBA 4(1). Maret: 223-230.

Langelo, F. D.P.E. Saerang dan S.W. Alexander. Analisis Penerapan Standar Akuntansi Pemerintahan Berbasis Akrual Dalam Penyajian Laporan Keuangan Pada Pemerintah Kota Bitung. Jurnal EMBA 3(1). Maret: 1-8.

Lubis, N.K. 2017. Pengaruh Tekanan Eksternal, Ketidakpastian Lingkungan dan Komitmen Manajemen Terhadap Transparansi Pelaporan Keuangan. JENSI Vol. 1 No. 1.

McLeod, R., Jr dan schell, 2001, Sistem Informasi Manajemen, Salemba Empat, Jakarta

Mahmudi. 2011. Akuntansi Sektor Publik. Cetakan Pertama. UII Press, Yogyakarta.

Mardiasmo. 2009. Akuntansi Sektor Publik. Yogyakarta : CV. Andi Offset.

Mardiyah, A. A. dan Gudono. 2001. Pengaruh Ketidakpastian Lingkungan dan Desentralisasi terhadap Karakteristik Sistem Akuntansi Manajemen. Jurnal riset Akuntansi Indonesia 4(1).

Mulyadi. 2006. Akuntansi Manajemen : Konsep, Manfaat dan Rekayasa, Edisi Kedua. Yogykarta: STIE YKPN.

Mulyani, R.A. 2015. Pengaruh Partisipasi Penyusunan Anggaran Terhadap Senjangan Anggaran Dengan Budget Emphasis Sebagai Variabel Moderasi. Universitas Pendidikan Indonesia repository.upi.edu perpustakaan.upi.edu.

Peraturan Pemerintah Nomor 24 tahun 2005 tentang Standar Akuntansi Pemerintah.

Peraturan Pemerintah Nomor 71 Tahun 2010 tentang Standar Akuntansi Pemerintah. 
Prasetiyo, F.T. 2016 Pengaruh Ketidakpastian Lingkungan, dan Desentralisasi, Terhadap Hubungan Antara Karakteristik Sistem Akuntansi Manajemen Dengan Kinerja Manajerial (Studi Kasus Pada PT. Kebayoran Pharma).

Putri, D. U dan Silviana. 2017. Pengaruh Kompetensi Sumber Daya Manusia, Komitmen Organisasi dan Fungsi Komunikasi Terhadap Penerapan Standar Akuntansi Pemerintah Berbasis Akrual Pada Satuan Kerja Perangkat Daerah Di Kota Bandung. ISSN-SNAB252-3936.

Ranuba, E.D.S, S. Pangemanan dan S. Pinatik. 2015. Analisis Kesiapan Penerapan Standar Akuntansi Pemerintah Berbabis Akrual Berdasarkan PP No.71 Tahun 2010 Pada DPKPA Minahasa Selatan. Jurnal EMBA 3(1). Maret: 388-397.

Rahayu, Y.A. 2013. Pengaruh Desentralisasi, Karakteristik Sistem Informasi Akuntansi Manajemen dan teknologi Informasi terhadap Kinerja Manajerial. Skripsi Universitas Pasundan.

Rini, D.D.O. 2007. Pengaruh Ketidakpastian Lingkungan, Desentralisasi dan Pembebanan Tugas Terhadap Akuntanbilitas Kinerja. Tesis STIESIA

Ritonga, I. T. 2010. Akuntansi Pemerintah Daerah. Yogyakarta : Sekolah Pasca Sarjana UGM.

Rizna, 2009. Pengaruh Budaya Kerja dan Motivasi Kerja Terhadap Komitmen Kerja Karyawan. Skripsi Fakultas Ekonomi, Universitas Sumatera Utara, Medan.

Robbins, S. P dan M. Coulter . 2010. Manajemen. Jilid 1/ Stephen P Robbins dan Mary Coulter diterjemahkan oleh Bob Sabran, Wibi Hardani. - Ed.10, Cet.13 - Jakarta: Erlangga.

Rosalin, F. 2011. Faktor-Faktor yang Mempengaruhi Keandalan dan
Timeliness Pelaporan Keuangan Badan Layanan Umum (Studi pada BLU di Kota Semarang). Skripsi Universitas Diponegoro: Semarang

Rudianto. 2006. Akuntansi Manajemen. Jakarta: PT Gramedia.

Simamora, H. 2012. Akuntansi Manajemen. Edisi Ketiga. Riau: Star Gate Publisher.

Simanjuntak, B. H. 2010. Penerapan Akuntansi Berbasis di Sektor Pemerintahan Di Indonesia. Disampaikan Pada Kongres XI Ikatan Akuntansi Indonesia. Jakarta 9 Desember 2010.

Sugiyono. 2013. Metode Penelitian Kuantitatif, Kualitatif, dan Kombinasi (Mixed Methods). Alfabeta. Bandung.

Tahyudin. 2013. Pengaruh Sistem Informasi Akuntansi, Ketidakpastian Tugas, Desentralisasi, dan Ketidakpastian Lingkungan terhadap Kinerja Manajerial. Skripsi Universitas Pasundan. Bandung.

Tanjung, H.A. 2012. Akuntansi Pemerintah Berbasis Akrual Pendekatan Teknis Sesuai PP No. 71/2010. Bandung: Alfabeta

Tjahjadi, B. 2008. Hubungan Sistem Manajemen Risiko Dengan Ketidakpastian Lingkungan Dan Strategi Serta DampaknyaTerhadap Kinerja Organisasi, Universitas Diponogoro: Semarang

Widjajarso, B. 2008. Penerapan Basis Akrual Pada Akuntansi Pemerintah Indonesia: Sebuah Kajian Pendahuluan.

Wiryaningsih, N.N.D, N.L.G.E. Sulindawati dan M.A. Prayudi. 2017. Analisis Penerapan Peraturan Pemerintah Nomor 71 Tahun 2010 Tentang Standar Akuntansi Pemerintah Berbasis Akrual Pada Rumah Sakit Umum Kabupaten Bangli. e-Jurnal $S 1$ Ak. Universitas Pendidikan Ganesha $8(2)$. 